\title{
Mortality among members of a heavy construction equipment operators union with potential exposure to diesel exhaust emissions
}

\author{
O WONG, R W MORGAN, L KHEIFETS, S R LARSON, AND M D WHORTON \\ From Environmental Health Associates Inc, Oakland, CA 94607, USA
}

\begin{abstract}
A historical prospective mortality study was conducted on a cohort of 34156 male members of a heavy construction equipment operators union with potential exposure to diesel exhaust emissions. This cohort comprised all individuals who were members of the International Union of Operating Engineers, Locals 3 and 3A, for at least one year between 1 January 1964 and 31 December 1978. The mortality experience of the entire cohort and several subcohorts was compared with that of United States white men, adjusted for age and calendar time. The comparison statistic was the commonly used standardised mortality ratio (SMR). Historical environmental measurements did not exist, but partial work histories were available for some cohort members through the union dispatch computer tapes. An attempt was made to relate mortality experience to the union members' dispatch histories. Overall mortality for the entire cohort and several subgroups was significantly lower than expected. When cause specific mortality was examined, however, the study provided suggestive evidence for the existence of several potential health problems in this cohort. Mortality from liver cancer for the entire cohort was significantly high. Although mortality from lung cancer for the entire cohort was similar to expected, a positive trend by latency was observed for lung cancer. A significant excess of mortality from lung cancer was found among the retirees and the group for whom no dispatch histories were available. Other dispatch groups showed no evidence of lung cancer excess. In addition, the total cohort experienced significant mortality excess from emphysema and accidental deaths.
\end{abstract}

The potential adverse health effects of exposure to diesel exhaust emissions have recently gained considerable attention in the scientific community. This concern is even greater within federal regulatory agencies, partly because of the projected rise in the number of diesel powered cars in this decade. For both medical and economic reasons, it is important to investigate the implications of such a trend to public health.

Diesel exhaust emissions consist of a mixture of gases and particles, including carbon monoxide, oxides of nitrogen and sulphur, and particulates, which contain traces of the polycyclic aromatic hydrocarbons.' Exhaust emissions from some current diesel engines contain compounds that are mutagenic and carcinogenic in short term in vitro

Received 13 August 1984

Accepted 1 October 1984 tests $^{2}$; the significance of these findings to human health is as yet unknown.

Limited epidemiological data on the health consequences of exposure to diesel exhaust emissions are available from a few studies. ${ }^{3-8}$ These few relevant studies have been summarised in a recent review article. ${ }^{y}$ The findings from these studies will not be discussed here, except to note that the results cannot rule out a carcinogenic effect on the lung from occupational exposure to diesel engine exhaust.

Because of this uncertainty, a historical prospective mortality study of heavy construction equipment workers, many of whom were potentially exposed to diesel exhaust emissions, was conducted by Environmental Health Associates, Inc (EHA). This work was supported under contract to the Coordinating Research Council (CRC) and accomplished in conjunction with the International Union of Operating Engineers, Local No 3, and C W 
Sweeney \& Co trust fund administrators.

\section{Methods and material}

Study cohort members were identified from records maintained at Operating Engineers Local Union No 3, San Francisco. This union consists of six subdivisions; 3, 3A, 3B, 3C, 3D, and 3E. Heavy construction equipment operators are members of locals 3 or $3 \mathrm{~A}$ only and are believed to be exposed to diesel exhaust during the course of their work. Locals 3 or $3 \mathrm{~A}$ are referred to here as "local 3-3A" or simply the "union" and all six sublocals as "local 3." The jurisdiction of local 3 includes Northern California, Utah, Hawaii, Nevada, and Guam.

Local 3-3A is a well established union that maintains both work and death records for its members. Membership records have been computerised since 1964 and information before that time is filed on microfiche. In addition, death certificates since 1968 are available from the union.

From these records maintained at the union, individuals with at least one year of membership in local 3-3A between 1 January 1964 and 31 December 1978 were included in the study. Other local 3 members were not included. Duration of membership was defined as the duration between "initiation" date and "dues paid through" date.

Demographic information, such as name, social security number, birthdate, state of residence, and date of death (if available), were abstracted from union records. In addition, union membership information such as initiation date, dues paid through date, union membership status, and union registration number were also abstracted.

Work histories of the cohort members were obtained through job dispatch computer tapes maintained at the union. The union provided 12 annual dispatch tapes between 1967 (earliest year available) and 1978, recording all job dispatches for local 3-3A during these 12 years. It should be pointed out here that using these dispatch tapes as surrogates of employment histories has several limitations. Firstly, no information before 1967 was available. For those whose initiation date was before 1967 , the early part of their work histories was not available. Secondly, those union members whose jobs remained the same before and after 1967-that is, no new job dispatch-would not appear on the dispatch tapes at all. Nevertheless, this is the only centralised and readily accessible source for work histories.

In addition to local 3-3A, certain information was available from C W Sweeney \& Co, trust fund administrators. This company is an independent administrator for numerous trust funds, including local 3-3A. Payment on behalf of each employee is
Table 1 Distribution by union membership status (as of 31 December 1978) of the total cohort of local 3-3A members

\begin{tabular}{llc}
\hline Union membership & Frequency & Percentage \\
\hline Active & 15735 & $46 \cdot 1 \%$ \\
Terminated & 10505 & $30 \cdot 8 \%$ \\
Retired & 6680 & $19.6 \%$ \\
Died while active & 1236 & $3.6 \%$ \\
$\quad$ or retired & 34156 & $100 \cdot 0 \%$ \\
\hline
\end{tabular}

made directly to the fund by the employer and is proportional to the number of hours worked by the employee.

The fund was begun in 1958 and no one retired before 1960. Computerisation of fund files occurred in 1967 , at which time a separate file of all retirees was created. Death information on the retiree file is accurate because payment of benefits is dependent on it.

The fund provided information on retirement data, vital status, and date of death on those individuals who were entitled to retirement and death benefits from the fund.

The study included the 34156 male members of local 3-3A who satisfied the cohort criteria; table 1 shows the union membership status of the entire cohort. As of 31 December 1978, 15735 cohort members $(46.1 \%)$ were active members of the union; $10505(30.8 \%)$ terminated or inactive; 6670 $(19.6 \%)$ retired; and $1238(3.6 \%)$ had died while an active or retired member.

As mentioned above, duration of union membership was defined as the duration between membership initiation date and union dues paid through date. For those who had retired, a retirement date was available from the fund. In these cases the retirement date was used in place of union dues paid through date, since dues were paid on a quarterly basis and the paid through date might go beyond one's active employment in the industry and thus slightly overstate the duration of employment in the industry. About half of the cohort had been union members for under 15 years; the other half 15 years or more. The average duration of membership was $15 \cdot 0$ years.

It was necessary to ascertain the vital status of the 10505 cohort members who left the union before the end of the observation period, 31 December 1978. Names and social security numbers of these individuals were sent to the Social Security of Administration (SSA). The SSA determined that 6633 were living, 2107 had died, and $1765 \stackrel{\mathscr{C}}{\rightarrow}$ remained as unknown. As of 31 December 1978, 29046 cohort members $(85.0 \%)$ were still living, $3345(9.8 \%)$ had died, and $1765(5.2 \%)$ remained unknown vital status (table 2). 
Table 2 Distribution by vital status (as of 31 December 1978) of the total cohort of local 3-3A members

\begin{tabular}{lrc}
\hline Vital status & Frequency & Percentage \\
\hline Living & 29046 & $85.0 \%$ \\
Dead & 3345 & $9.8 \%$ \\
$\begin{array}{l}\text { With death certificates } \\
\text { Without death } \\
\quad \text { certificates }\end{array}$ & $(3243)$ & $(96.9 \%)$ \\
$\begin{array}{l}\text { Unknown } \\
\text { Total }\end{array}$ & $1765(102)$ & $5.2 \%$ \\
\hline
\end{tabular}

Date and place of death were obtained for those who had died from either the union, the fund, or the SSA. Requests were sent to the appropriate state vital statistics departments for copies of death certificates. Of the 3345 dead cohort members, death certificates were obtained for all but 102 individuals $(3.1 \%)$. For these 102 presumed deaths, only date of death, but no cause of death, was available.
Results

Race was not always available from membership records; however, according to the union, there were few, if any, non-white members before 1970 . In our analysis the entire cohort will be assumed to consist of white men only.

Causes of death were coded by a trained nosologist according to the rules in effect at the time of death, and then converted into codes in the 7 th revision of the International Classification of Diseases. ${ }^{10}$ Altogether 3345 deaths in the cohort were coded.

Analysis was based on the standardised mortality ratio (SMR). The United States national age-sexrace-cause-specific mortality rates for five year periods from 1964 to 1978 were used in calculating the expected deaths. The statistical analysis was performed using a standard computer program."

Although death certificates were not obtained for

Table 3 Observed and expected deaths by cause, SMRs, and their 95\% confidence limits for the entire cohort of 34156 male local 3-3A members. (No of subjects $=34156$, person-years $=372525.6$ )

\begin{tabular}{|c|c|c|c|c|c|}
\hline $\begin{array}{c}\text { Cause of death } \\
\text { (7th ICDA) }\end{array}$ & $\begin{array}{l}\text { Obs } \\
\text { deaths }\end{array}$ & $\begin{array}{l}\text { Expected } \\
\text { deaths }\end{array}$ & $S M R$ & $\begin{array}{l}\text { Lower } \\
\text { limit }\end{array}$ & $\begin{array}{l}\text { Upper } \\
\text { limit }\end{array}$ \\
\hline 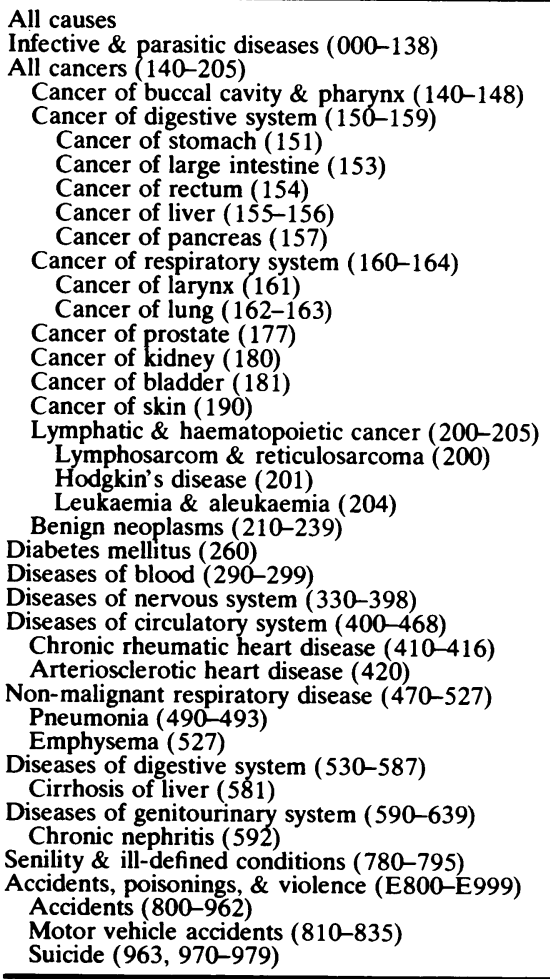 & $\begin{array}{r}3345 \\
20 \\
817 \\
23 \\
211 \\
44 \\
66 \\
12 \\
23 \\
47 \\
320 \\
10 \\
309 \\
37 \\
17 \\
27 \\
16 \\
72 \\
19 \\
9 \\
25 \\
16 \\
36 \\
6 \\
169 \\
1311 \\
21 \\
1047 \\
196 \\
41 \\
116 \\
160 \\
107 \\
8 \\
3 \\
14 \\
474 \\
348 \\
139 \\
101\end{array}$ & $\begin{array}{r}4109.47 \\
30.03 \\
878.34 \\
29.87 \\
226.13 \\
37.41 \\
74 \cdot 63 \\
24 \cdot 80 \\
13 \cdot 80 \\
48 \cdot 63 \\
330.30 \\
13.98 \\
313.44 \\
42.47 \\
23.01 \\
22.86 \\
16.55 \\
85.16 \\
19.24 \\
10.29 \\
32.26 \\
10.59 \\
58.54 \\
8.06 \\
265.55 \\
1822.49 \\
35.89 \\
1543.81 \\
232.30 \\
75.96 \\
70.17 \\
221 \cdot 23 \\
133.52 \\
40.33 \\
13.98 \\
53.57 \\
425 \cdot 61 \\
273.96 \\
129 \cdot 11 \\
103.64\end{array}$ & $\begin{array}{c}81 \cdot 4 \dagger \\
66 \cdot 6 \\
93 \cdot 0^{*} \\
77 \cdot 0 \\
93 \cdot 3 \\
117 \cdot 6 \\
88 \cdot 4 \\
48 \cdot 4 \dagger \\
166 \cdot 7^{*} \\
96 \cdot 6 \\
96 \cdot 9 \\
71 \cdot 6 \\
98 \cdot 6 \\
87 \cdot 1 \\
73 \cdot 9 \\
118 \cdot 1 \\
96 \cdot 7 \\
84 \cdot 5 \\
98 \cdot 8 \\
87 \cdot 5 \\
77 \cdot 5 \\
151 \cdot 0 \\
61 \cdot 5 \dagger \\
74 \cdot 5 \\
63 \cdot 6 \dagger \\
71 \cdot 9 \dagger \\
58 \cdot 5^{*} \\
67 \cdot 8 \dagger \\
84 \cdot 4^{*} \\
54 \cdot 0 \dagger \\
165 \cdot 3 \dagger \\
72 \cdot 3 \dagger \\
80 \cdot 1^{*} \\
19 \cdot 8 \dagger \\
21 \cdot 5 \dagger \\
26 \cdot 1 \dagger \\
111 \cdot 4^{*} \\
127 \cdot 0 \dagger \\
107 \cdot 7 \\
97 \cdot 5 \\
\end{array}$ & $\begin{array}{r}78 \cdot 7 \\
40 \cdot 6 \\
86 \cdot 7 \\
48 \cdot 7 \\
81 \cdot 1 \\
85 \cdot 5 \\
68 \cdot 4 \\
24 \cdot 9 \\
105 \cdot 5 \\
71 \cdot 0 \\
86 \cdot 5 \\
34 \cdot 4 \\
87 \cdot 8 \\
61 \cdot 2 \\
42 \cdot 9 \\
77 \cdot 7 \\
55 \cdot 2 \\
66 \cdot 3 \\
59 \cdot 5 \\
40 \cdot 1 \\
50 \cdot 0 \\
86 \cdot 3 \\
42 \cdot 9 \\
27 \cdot 3 \\
54 \cdot 4 \\
68 \cdot 1 \\
36 \cdot 1 \\
63 \cdot 8 \\
73 \cdot 0 \\
38 \cdot 7 \\
136 \cdot 5 \\
61 \cdot 6 \\
65 \cdot 6 \\
8 \cdot 5 \\
4 \cdot 4 \\
14 \cdot 3 \\
101 \cdot 6 \\
114 \cdot 0 \\
90 \cdot 5 \\
79 \cdot 3\end{array}$ & $\begin{array}{r}84 \cdot 2 \\
103 \cdot 0 \\
99 \cdot 6 \\
115 \cdot 6 \\
106 \cdot 8 \\
158 \cdot 0 \\
112 \cdot 6 \\
84 \cdot 4 \\
250 \cdot 3 \\
128 \cdot 6 \\
108 \cdot 1 \\
131 \cdot 5 \\
110 \cdot 2 \\
120 \cdot 2 \\
118 \cdot 2 \\
171 \cdot 9 \\
156 \cdot 9 \\
106 \cdot 6 \\
154 \cdot 3 \\
166 \cdot 0 \\
114 \cdot 3 \\
245 \cdot 2 \\
85 \cdot 2 \\
162 \cdot 3 \\
74 \cdot 0 \\
75 \cdot 9 \\
89 \cdot 5 \\
72 \cdot 1 \\
97 \cdot 0 \\
73 \cdot 3 \\
198 \cdot 4 \\
84 \cdot 4 \\
96 \cdot 9 \\
39 \cdot 0 \\
62 \cdot 8 \\
43 \cdot 8 \\
121 \cdot 9 \\
141 \cdot 0 \\
127 \cdot 2 \\
118 \cdot 5\end{array}$ \\
\hline
\end{tabular}

${ }^{*}$ Statistically significant at $0-05$ level.

†Statistically significant at 0.01 level. 
102 individuals, their date of death was known. These deaths were included in the overall mortality analysis but not in the cause specific analysis.

CAUSE SPECIFIC MORTALITY OF ENTIRE COHORT Table 3 shows the observed and expected deaths by cause, SMRs, and their $95 \%$ confidence limits for the entire cohort of 34156 male members of local 3-3A. A total of 3345 deaths was observed, compared with 4109.47 expected. The corresponding SMR for all causes was $81 \cdot 4$, statistically significant at the 0.01 level.

A total of 817 deaths was attributed to malignant neoplasms, slightly fewer than the expected 878.34 based on the United States white male cancer mortality rates $(S M R=93.0, p<0.05)$. Some of the site specific cancer mortality observed in the cohort deviated much more from the expected, however, although only for two sites were the deviations statistically significant.

As a whole, for cancer of the digestive system, 211 deaths were observed, slightly fewer than the 226.13 expected. Only 12 deaths were attributed to cancer of the rectum, however, fewer than half the expected, $24 \cdot 80$. The corresponding SMR of $48 \cdot 4$ was significant at the 0.01 level. On the other hand, 23 deaths were due to cancer of the liver, when only 13.80 were expected, the SMR being 166.7 ( $p<$ $0.05)$.

A total of 320 cohort members died from cancer of the respiratory system, which was slightly, but not significantly, less than the $\mathbf{3 3 0} \cdot 30$ expected (SMR = 96.9). Of the 320 deaths from respiratory cancer, 10 were coded as cancer of the larynx and 309 cancer of the lung, bronchus, and trachea.

For cancer of the bladder and benign neoplasms,

Table 4 Observed deaths and SMRs by cause and duration of union membership for the entire cohort of 34156 male local 3-3A $\rightarrow$ members

\begin{tabular}{|c|c|c|c|c|c|c|c|c|c|c|}
\hline \multirow[t]{3}{*}{ Cause of death (7th ICDA) } & \multicolumn{10}{|c|}{ Duration of union membership (years) } \\
\hline & \multicolumn{2}{|l|}{$<5$} & \multicolumn{2}{|l|}{$5-9$} & \multicolumn{2}{|c|}{$10-14$} & \multicolumn{2}{|c|}{$15-19$} & \multicolumn{2}{|l|}{$\geqslant 20$} \\
\hline & Obs & $S M R$ & Obs & $S M R$ & Obs & $S M R$ & Obs & $S M R$ & Obs & SMR ワ \\
\hline $\begin{array}{l}\text { All causes } \\
\text { All cancers (140-205) }\end{array}$ & $\begin{array}{r}278 \\
39\end{array}$ & $\begin{array}{l}75 \cdot 2 \dagger \\
58 \cdot 1 \dagger\end{array}$ & $\begin{array}{r}389 \\
96\end{array}$ & $\begin{array}{l}78 \cdot 2 \dagger \\
98 \cdot 5\end{array}$ & $\begin{array}{l}544 \\
136\end{array}$ & $\begin{array}{l}82.4 \dagger \\
98.4\end{array}$ & $\begin{array}{l}608 \\
153\end{array}$ & $\begin{array}{l}84 \cdot 1 \dagger \\
97 \cdot 6\end{array}$ & $\begin{array}{r}1526 \\
393\end{array}$ & $\begin{array}{l}82 \cdot 1+\frac{\sum}{2} \\
93.9\end{array}$ \\
\hline $\begin{array}{l}\text { Cancer of digestive system } \\
\text { (150-159) } \\
\text { Cancer of stomach (151) } \\
\text { Cancer of large intestine (153) } \\
\text { Cancer of liver (155-156) }\end{array}$ & $\begin{array}{l}15 \\
3 \\
4 \\
1\end{array}$ & $\begin{array}{r}94 \cdot 1 \\
112 \cdot 5 \\
76 \cdot 9 \\
101 \cdot 1\end{array}$ & $\begin{array}{r}29 \\
10 \\
7 \\
4\end{array}$ & $\begin{array}{c}120 \cdot 7 \\
248 \cdot 4^{*} \\
89 \cdot 6 \\
273 \cdot 4\end{array}$ & $\begin{array}{r}37 \\
6 \\
6 \\
9\end{array}$ & $\begin{array}{c}105 \cdot 7 \\
103 \cdot 1 \\
52 \cdot 5 \\
424 \cdot 1 \dagger\end{array}$ & $\begin{array}{r}39 \\
9 \\
13 \\
1\end{array}$ & $\begin{array}{r}96 \cdot 5 \\
134 \cdot 5 \\
97 \cdot 9 \\
40 \cdot 9\end{array}$ & $\begin{array}{r}91 \\
16 \\
36 \\
8\end{array}$ & 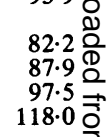 \\
\hline $\begin{array}{l}\text { Cancer of respiratory system } \\
(160-164) \\
\text { Cancer of lung }(162-163) \\
\text { Cancer of prostate }(177) \\
\text { Cancer of kidney }(180) \\
\text { Cancer of bladder }(181) \\
\text { Cancer of skin }(190) \\
\text { Lymphatic \& haematopoietic }\end{array}$ & $\begin{array}{r}10 \\
10 \\
1 \\
0 \\
3 \\
1\end{array}$ & $\begin{array}{c}42.9 \dagger \\
45.3 \dagger \\
52.1 \\
\overline{231} \\
50.7\end{array}$ & $\begin{array}{r}26 \\
25 \\
2 \\
4 \\
4 \\
2\end{array}$ & $\begin{array}{r}73.8 \\
74.9 \\
60.4 \\
152.0 \\
192.1 \\
79.6\end{array}$ & $\begin{array}{r}55 \\
53 \\
5 \\
3 \\
2 \\
4\end{array}$ & $\begin{array}{r}105.9 \\
107.5 \\
91.3 \\
80.0 \\
61.5 \\
133.0\end{array}$ & $\begin{array}{r}61 \\
58 \\
7 \\
4 \\
4 \\
2\end{array}$ & $\begin{array}{r}102.0 \\
102.2 \\
95.9 \\
95 \cdot 9 \\
99 \cdot 4 \\
68.9\end{array}$ & $\begin{array}{c}168 \\
163 \\
22 \\
6 \\
14 \\
7\end{array}$ & 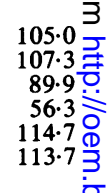 \\
\hline $\begin{array}{l}\text { cancer }(200-205) \\
\text { Lymphosarcoma \& }\end{array}$ & 5 & $57 \cdot 2$ & 13 & $116 \cdot 1$ & 14 & $99 \cdot 5$ & 9 & $61 \cdot 0$ & 31 & $85 \cdot 2 \underline{\underline{\sigma}}$. \\
\hline $\begin{array}{l}\text { reticulosarcoma (200) } \\
\text { Leukaemia \& aleukaemia }\end{array}$ & 1 & $51 \cdot 3$ & 2 & $77 \cdot 5$ & 3 & $91 \cdot 7$ & 3 & $88 \cdot 3$ & 10 & 124.4 으ำ \\
\hline (204) & 2 & $60 \cdot 6$ & 6 & $143 \cdot 3$ & 3 & $57 \cdot 1$ & 3 & $54 \cdot 0$ & 11 & $78 \cdot 8$ \\
\hline $\begin{array}{l}\text { Diseases of nervous system } \\
(330-398)\end{array}$ & 9 & $47 \cdot 0^{*}$ & 15 & $53 \cdot 3^{*}$ & 19 & $47 \cdot 9 \dagger$ & 23 & $49 \cdot 6 \dagger$ & 103 & 77 . \\
\hline $\begin{array}{l}\text { Diseases of circulatory system } \\
(400-468) \\
\text { Arteriosclerotic heart disease }\end{array}$ & 88 & $66 \cdot 6 \dagger$ & 130 & $65 \cdot 3 \dagger$ & 201 & $70 \cdot 3 \dagger$ & 239 & $72 \cdot 9 \dagger$ & 653 & 74 . \\
\hline $\begin{array}{l}(420) \\
\text { Non-malionant respiratory disease }\end{array}$ & 66 & $59 \cdot 7 \dagger$ & 107 & $63.8 \dagger$ & 155 & $64 \cdot 0 \dagger$ & 198 & $71 \cdot 1 \dagger$ & 521 & 69.9 ద \\
\hline $\begin{array}{l}\text { Non-malignant respiratory disease } \\
\text { (470-527) } \\
\text { Emphysema (527) }\end{array}$ & $\begin{array}{l}6 \\
4\end{array}$ & $\begin{array}{l}38 \cdot 0 \dagger \\
99 \cdot 0\end{array}$ & $\begin{array}{r}14 \\
7\end{array}$ & $\begin{array}{c}59 \cdot 4^{*} \\
107 \cdot 2\end{array}$ & $\begin{array}{l}31 \\
16\end{array}$ & $\begin{array}{r}90 \cdot 2 \\
158 \cdot 7\end{array}$ & $\begin{array}{l}34 \\
24\end{array}$ & $\begin{array}{c}83 \cdot 4 \\
194 \cdot 6 \dagger\end{array}$ & $\begin{array}{r}111 \\
65\end{array}$ & $\begin{array}{r}94.2 \mathrm{~N} \\
174.8 \mathrm{~N}\end{array}$ \\
\hline $\begin{array}{l}\text { Diseases of digestive system } \\
\quad(530-587) \\
\text { Cirrhosis of liver }(581)\end{array}$ & $\begin{array}{r}13 \\
8\end{array}$ & $\begin{array}{l}60 \cdot 6 \\
58 \cdot 6\end{array}$ & $\begin{array}{l}20 \\
14\end{array}$ & $\begin{array}{l}66 \cdot 8 \\
73 \cdot 7\end{array}$ & $\begin{array}{l}22 \\
14\end{array}$ & $\begin{array}{l}56 \cdot 4 \dagger \\
57 \cdot 0^{*}\end{array}$ & $\begin{array}{l}32 \\
22\end{array}$ & $\begin{array}{l}79 \cdot 2 \\
88 \cdot 7\end{array}$ & $\begin{array}{l}73 \\
49\end{array}$ & ${ }_{95 \cdot 2}^{80 \cdot 8}$ \\
\hline $\begin{array}{l}\text { Diseases of genitourinary system } \\
\text { (590-639) } \\
\text { Chronic nephritis (592) }\end{array}$ & $\begin{array}{l}\mathbf{0} \\
\mathbf{0}\end{array}$ & 二 & $\begin{array}{l}3 \\
1\end{array}$ & $\begin{array}{l}62 \cdot 5 \\
50.6\end{array}$ & $\begin{array}{l}2 \\
0\end{array}$ & $\mathbb{3}^{31 \cdot 9}$ & $\begin{array}{l}2 \\
2\end{array}$ & $\begin{array}{l}28 \cdot 7 \\
83 \cdot 1\end{array}$ & 0 & $\begin{array}{r}5.3 \frac{0}{10} \\
-\quad 00\end{array}$ \\
\hline $\begin{array}{l}\text { Accidents, poisonings, \& violence } \\
\text { (E800-E999) } \\
\text { Accidents }(800-962) \\
\text { Suicide }(963,970-979)\end{array}$ & $\begin{array}{l}97 \\
72 \\
20\end{array}$ & $\begin{array}{l}111 \cdot 1 \\
124 \cdot 0 \\
108 \cdot 9\end{array}$ & $\begin{array}{l}88 \\
67 \\
16\end{array}$ & $\begin{array}{r}103 \cdot 7 \\
122 \cdot 0 \\
81 \cdot 7\end{array}$ & $\begin{array}{r}101 \\
75 \\
20\end{array}$ & $\begin{array}{l}127 \cdot 7^{*} \\
149 \cdot 9 \dagger \\
101 \cdot 4\end{array}$ & $\begin{array}{l}79 \\
52 \\
22\end{array}$ & $\begin{array}{l}122 \cdot 8 \\
127 \cdot 9 \\
131 \cdot 6\end{array}$ & $\begin{array}{r}109 \\
82 \\
23\end{array}$ & $\begin{aligned} & 99 \cdot 1 \frac{0}{116 \cdot 2} \\
& 78 \cdot 8 \frac{D^{\circ}}{D}\end{aligned}$ \\
\hline $\begin{array}{l}\text { *Statistically significant at } 0.05 \\
\text { tStatistically significant at } 0.01\end{array}$ & & & & & & & & & & 2 \\
\hline
\end{tabular}


the SMRs were $118 \cdot 1$ and $151 \cdot 0$, respectively; neither was statistically significant. Cancer mortality for all other sites examined was slightly less than expected, but none of the deficits was statistically significant.

Significant mortality deficits were observed for the following conditions: diabetes mellitus, disease of the nervous system and sense organs, disease of the circulatory system, pneumonia, disease of the digestive system (including cirrhosis of the liver), and disease of the genitourinary system.

Mortality from emphysema for the entire cohort was significantly raised. With 116 observed deaths and only 70.17 expected, the emphysema SMR was $165 \cdot 3$, statistically significant at the $0 \cdot 01$ level.

Accidental deaths among members of the union were also significantly higher than those in a comparable group of United States white men. A total of 348 union members died from accidents, compared with an expected 278.96. The corresponding SMR of 127.0 was statistically significant at the 0.01 level.

\section{CAUSE SPECIFIC MORTALITY BY DURATION OF UNION MEMBERSHIP}

In the present study duration of union membership was used as a surrogate measure of duration of potential exposure to diesel exhaust emissions. Table 4 presents selected cause specific observed deaths and SMR by five categories of duration of union membership for the entire cohort. For all causes, the SMR remained fairly constant around 80 across all five categories. For all cancers, the SMR for under five years of membership was only $58 \cdot 1$, a statistically significant deficit at the 0.01 level. With longer membership, the SMR for all cancers increased to around 98. No obvious trend was detected for any site specific cancer, except for cancer of the lung. For cancer of the lung, the SMR

Table 5 Observed deaths and SMRs by cause and latency for the entire cohort of 34156 male local 3-3A members

\begin{tabular}{|c|c|c|c|c|c|c|}
\hline \multirow[t]{3}{*}{ Cause of death (7th ICDA) } & \multicolumn{6}{|c|}{ Latency (years) } \\
\hline & \multicolumn{2}{|l|}{$<10$} & \multicolumn{2}{|l|}{$10-19$} & \multicolumn{2}{|l|}{$\geqslant 20$} \\
\hline & Obs & $S M R$ & Obs & $S M R$ & Obs & $S M R$ \\
\hline All causes & 505 & $71 \cdot 5 t$ & 1055 & $80 \cdot 3 \dagger$ & 1785 & $85 \cdot 4 \dagger$ \\
\hline \multirow{2}{*}{\multicolumn{7}{|c|}{$\begin{array}{l}\text { All cancers }(140-205) \\
\text { Cancer of digestive system }\end{array}$}} \\
\hline & & & & & & \\
\hline Cancer of stomach (151) & $\begin{array}{l}31 \\
10\end{array}$ & $\begin{array}{l}100 \cdot 1 \\
190 \cdot 5\end{array}$ & $\begin{array}{l}68 \\
17\end{array}$ & $\begin{array}{r}96 \cdot 4 \\
145 \cdot 0\end{array}$ & $\begin{array}{r}112 \\
17\end{array}$ & $\begin{array}{l}89 \cdot 9 \\
83 \cdot 2\end{array}$ \\
\hline Cancer of large intestine (153) & 7 & 70.7 & 11 & $48.0 \dagger$ & 48 & $114 \cdot 7$ \\
\hline Cancer of liver $(155-156)$ & 3 & $154 \cdot 9$ & 11 & $257 \cdot 9 \dagger$ & 9 & 118.5 \\
\hline \multicolumn{7}{|l|}{ Cancer of respiratory system } \\
\hline$(160-164)$ & 29 & $64 \cdot 3^{*}$ & 93 & $87 \cdot 7$ & 198 & $110 \cdot 5$ \\
\hline Cancer of lung (162-163) & 28 & $65 \cdot 6^{*}$ & 90 & $89 \cdot 5$ & 191 & $112 \cdot 2$ \\
\hline Cancer of prostate (177) & 0 & - & 13 & $122 \cdot 9$ & 24 & $83 \cdot 6$ \\
\hline Cancer of kidney (180) & 4 & 114.4 & 6 & $78 \cdot 7$ & 7 & 58.9 \\
\hline Cancer of bladder (181) & 6 & $250 \cdot 2$ & 6 & $92 \cdot 7$ & 15 & $107 \cdot 2$ \\
\hline Cancer of skin (190) & 2 & $52 \cdot 4$ & 5 & $84 \cdot 7$ & 9 & $131 \cdot \overline{7}$ \\
\hline \multicolumn{7}{|l|}{ Lymphatic \& haematopoietic } \\
\hline \multicolumn{7}{|l|}{ Lymphosarcoma \& } \\
\hline reticulosarcoma (200) & 3 & $77 \cdot 6$ & 5 & $76 \cdot 9$ & 11 & $123 \cdot 9$ \\
\hline \multicolumn{5}{|l|}{ Leukaemia \& aleukaemia } & 13 & $82 \cdot 6$ \\
\hline \multicolumn{7}{|l|}{ Diseases of nervous system } \\
\hline$(330-398)$ & 15 & $41 \cdot 5 \dagger$ & 37 & $47 \cdot 4 \dagger$ & 117 & $77 \cdot 3 \dagger$ \\
\hline \multicolumn{7}{|l|}{ Diseases of circulatory system } \\
\hline \multicolumn{7}{|l|}{$\begin{array}{l}(400-468) \\
\text { Arteriosclerotic heart disease }\end{array}$} \\
\hline (420) & 119 & $54 \cdot 7 \dagger$ & 333 & $68 \cdot 1 \dagger$ & 595 & $71 \cdot 1 \dagger$ \\
\hline \multicolumn{7}{|l|}{ Non-malignant respiratory disease } \\
\hline Emphysema (527) & $\begin{array}{l}9 \\
4\end{array}$ & $\begin{array}{l}30.41 \\
50.9\end{array}$ & $\begin{array}{l}52 \\
28\end{array}$ & $\begin{array}{l}10 \cdot 3 \\
138 \cdot 6\end{array}$ & $\begin{array}{r}135 \\
84\end{array}$ & $\begin{array}{l}100 \cdot 3 \\
199 \cdot 4 \dagger\end{array}$ \\
\hline \multicolumn{7}{|l|}{ Diseases of digestive system } \\
\hline$(530-587)$ & 29 & $67 \cdot 2$ & 46 & $58.6 \dagger$ & 85 & $85 \cdot 4$ \\
\hline Cirrhosis of liver ( 581 ) & 18 & $55 \cdot 2$ & 32 & $64 \cdot 3 \dagger$ & 57 & $101 \cdot 5$ \\
\hline \multicolumn{7}{|l|}{ Diseases of genitourinary system } \\
\hline $\begin{array}{l}(590-639) \\
\text { Chronic nephritis (592) }\end{array}$ & 2 & $29 \cdot 4$ & 3 & $\begin{array}{l}24.5 \dagger \\
21.7\end{array}$ & 3 & $14 \cdot 1 \dagger$ \\
\hline \multicolumn{7}{|l|}{ Accidents, poisonings, \& violence } \\
\hline (E800-E999) & 172 & $109 \cdot 4$ & 178 & $120 \cdot 1^{*}$ & 124 & $103 \cdot 2$ \\
\hline Accidents $(800-962)$ & 129 & $124 \cdot 5 \dagger$ & 131 & $140.6 \dagger$ & 88 & $114 \cdot 1$ \\
\hline Suicide $(963,970-979)$ & 34 & 99.6 & 35 & $93 \cdot 1$ & 32 & $100 \cdot 4$ \\
\hline
\end{tabular}

*Statistically significant at $0 \cdot 05$ level.

†Statistically significant at $\mathbf{0 \cdot 0 1}$ level. 
started at $45 \cdot 3$ for under five years of membership, increased to 73.8 for five to nine years, reached 107.5 for $10-14$ years, and remained at that level for 15-19 and 20 and more years.

Mortality from cancer of the stomach was significantly high in the group with 5-9 years of membership. The SMR of 248.4 based on 10 deaths was significant at the $\mathbf{0 . 0 5}$ level. As mentioned earlier, mortality from liver cancer was significantly raised for the entire cohort. As table 4 indicates, the excess in liver cancer came from the group with 10-14 years of membership.

For diseases of the nervous system and sense organs, the SMR in all five duration of membership groups remained at the same level and significantly less than the expected. Similarly, for diseases of the circulatory system, the SMR in all five groups were significantly low.

The SMR for emphysema indicated an upward trend with increasing duration of membership. For those with under five years of membership, the SMR for emphysema was initially 99 ; increased steadily to a high of 194.6 for 15-19 years; and fell back slightly to 174.8 for 20 and more years.

No other trend was detected for the causes of death examined in table 4 . In particular, no trend was observed for accidental deaths. The excess in accidental death came from the group with 10-14 years of membership $(\mathrm{SMR}=149.9, \mathrm{p}<0.01)$.

\section{CAUSE SPECIFIC MORTALITY BY LATENT PERIOD}

For many chronic diseases, there is a long latent period between first exposure and death. Therefore, it is logical to examine mortality experience after a certain lag period has elapsed. Cause specific SMR by latency for the entire cohort are presented in table 5. For all causes, although the SMR in all three latent periods were significantly less than 100 , there was an upward trend with increasing latency. Perhaps this observation reflects the diminishing "healthy worker effect." Upward trends were also evident for all cancers, cancer of the lung, and cancer of the skin. It should also be pointed out that liver cancer excess came from the 10-19 latency group; the corresponding SMR of 257.9 based on 11 deaths being statistically significant at the 0.01 level.

Mortality from disease of the circulatory system (primarily arteriosclerotic heart disease) exhibited an increasing trend with prolonged latency. Obviously, this trend, perhaps the result of the diminishing healthy worker effect was the major contributor to that observed for all causes.

Several other points may be made based on the data in table 5 . In addition to a positive trend associated with latency, mortality from emphysema was significantly high for latency of 20 and more years
$($ SMR $=199.4, p<0.01)$. Interestingly, although there was a deficit in mortality from cirrhosis of the liver in all three latent periods, the SMR themselves increased with latency. There was no trend associated with accidental deaths, which is reassuring, since one would not expect accidental deaths to be related to latency.

\section{CAUSE SPECIFIC MORTALITY OF RETIREES}

Table 6 shows the mortality experience of the retirees in the cohort. A retiree was defined as anyone in the study with a retirement date during the study period. As mentioned earlier, the retirement date was obtained from the Sweeney Trust Fund. Among the 6678 retirees, 1345 had died. The corresponding SMR for all causes was $114 \cdot 5$, statistically significant at the 0.01 level. For cancer of all sites, the SMR was 145.3 (389 deaths observed $v$ 167.68 expected), significant at the 0.01 level. When specific sites were examined, a significant excess of mortality was observed in cancer of the digestive system $(\mathrm{SMR}=142.4, \mathrm{p}<0.01)$, cancer of the large intestine $(\mathrm{SMR}=181.8, \mathrm{p}<0.01)$, cancer of the respiratory system $(S M R=162.4, p<0.01)$, cancer of the lung (SMR $=164 \cdot 1, \mathrm{p}<0.01)$, and lymphosarcoma and reticulosarcoma $(\mathrm{SMR}=$ $231 \cdot 2, \mathrm{p}<0.05)$.

A significant excess of mortality was also found in non-malignant respiratory disease, the SMR being 129.0 and significant at the 0.05 level; this excess came primarily from emphysema. There were 75 deaths ascribed to emphysema, whereas only 27.05 were expected. The corresponding SMR of $277 \cdot 3$ was significant at the 0.01 level. Finally, mortality from cirrhosis of the liver was also significantly high ( 38 observed $v 21.90$ expected, $\mathrm{SMR}=173.5, \mathrm{p}<$ $0.01)$.

The retirees examined so far consisted of anyone with a retirement date during the study period, including early retirements, some of which might be related to ill health. To put the analysis of the retirees in the proper perspective, this selection factor needs to be adjusted. One common approach is to include these early retirees only when they reached age 65 , at which time the individual would retire normally. This definition of "normal" retiree appears to be the generally accepted definition for epidemiological research. ${ }^{12-14}$ Table 7 shows the cause specific mortality of the $\mathbf{4 0 7 5}$ normal retirees. Their overall mortality was significantly less than a comparable group of United States white men $($ SMR $=90.9, p<0.01)$. Nevertheless, all cancers showed a significant excess of $14.7 \%$. The major contributor to this excess was cancer of the lung. Among the normal retirees, 86 deaths were coded as cancer of the lung, compared with an expected of 
Table 6 Observed and expected deaths by cause, SMRs, and their 95\% confidence limits for all the retired male local 3-3A members. (No of subjects $=6678$, person-years $=32670 \cdot 1$ )

\begin{tabular}{|c|c|c|c|c|c|}
\hline $\begin{array}{c}\text { Cause of death } \\
\text { (7th ICDA) }\end{array}$ & $\begin{array}{l}\text { Obs } \\
\text { deaths }\end{array}$ & $\begin{array}{l}\text { Expected } \\
\text { deaths }\end{array}$ & $S M R$ & $\begin{array}{l}\text { Lower } \\
\text { limit }\end{array}$ & $\begin{array}{l}\text { Upper } \\
\text { limit }\end{array}$ \\
\hline $\begin{array}{l}\text { All causes } \\
\text { Infective \& parasitic diseases (000-138) } \\
\text { All cancers (140-205) } \\
\text { Cancer of buccal cavity \& pharynx (140-148) } \\
\text { Cancer of digestive system (150-159) } \\
\text { Cancer of stomach (151) } \\
\text { Cancer of large intestine (153) } \\
\text { Cancer of rectum (154) } \\
\text { Cancer of liver (155-156) } \\
\text { Cancer of pancreas (157) } \\
\text { Cancer of respiratory system (160-164) } \\
\text { Cancer of larynx (161) } \\
\text { Cancer of lung (162-163) } \\
\text { Cancer of prostate (177) } \\
\text { Cancer of kidney (180) } \\
\text { Cancer of bladder (181) } \\
\text { Cancer of skin (190) } \\
\text { Lymphatic \& haematopoietic cancer (200-205) } \\
\text { Lymphosarcom \& reticulosarcoma (200) } \\
\text { Hodgkin's disease (201) } \\
\text { Leukaemia \& aleukaemia (204) } \\
\text { Diabetes mellitus (260) } \\
\text { Diseases of blood (290-299) } \\
\text { Diseases of nervous system (330-398) } \\
\text { Diseases of circulatory system (400-468) } \\
\text { Chronic rheumatic heart disease (410-416) } \\
\text { Arteriosclerotic heart disease (420) } \\
\text { Non-malignant respiratory disease (470-527) } \\
\text { Pneumonia (490-493) } \\
\text { Emphysema (527) } \\
\text { Diseases of digestive system (530-587) } \\
\text { Cirrhosis of liver (581) } \\
\text { Diseases of genitourinary system (590-639) } \\
\text { Chronic nephritis (592) } \\
\text { Senility \& ill-defined conditions (780-795) } \\
\text { Accidents, poisonings, \& violence (E800-E999) } \\
\text { Accidents (800-962) } \\
\text { Motor vehicle accidents (810-835) } \\
\text { Suicide ( } 963,970-979)\end{array}$ & $\begin{array}{r}1345 \\
7 \\
389 \\
11 \\
103 \\
14 \\
46 \\
5 \\
9 \\
20 \\
161 \\
5 \\
155 \\
21 \\
5 \\
8 \\
6 \\
28 \\
10 \\
0 \\
8 \\
15 \\
2 \\
92 \\
562 \\
6 \\
438 \\
112 \\
19 \\
75 \\
52 \\
38 \\
3 \\
1 \\
2 \\
45 \\
26 \\
9 \\
19\end{array}$ & $\begin{array}{r}1174 \cdot 56 \\
7 \cdot 30 \\
267 \cdot 68 \\
7 \cdot 89 \\
72 \cdot 34 \\
11 \cdot 76 \\
25 \cdot 30 \\
7 \cdot 87 \\
4 \cdot 36 \\
15 \cdot 26 \\
99 \cdot 11 \\
3.99 \\
94 \cdot 46 \\
21 \cdot 71 \\
6 \cdot 23 \\
9 \cdot 27 \\
3 \cdot 15 \\
22 \cdot 35 \\
4 \cdot 33 \\
1.41 \\
8.97 \\
18 \cdot 28 \\
2.41 \\
98 \cdot 39 \\
562.60 \\
7 \cdot 89 \\
476 \cdot 31 \\
86 \cdot 80 \\
25 \cdot 31 \\
27 \cdot 05 \\
45 \cdot 34 \\
21.90 \\
13 \cdot 16 \\
3.21 \\
12.77 \\
45 \cdot 08 \\
30.00 \\
10.79 \\
11 \cdot 53\end{array}$ & $\begin{array}{c}114 \cdot 5 \dagger \\
95 \cdot 9 \\
145 \cdot 3 \dagger \\
139 \cdot 4 \\
142 \cdot 4 \dagger \\
119 \cdot 1 \\
181 \cdot 8 \dagger \\
63 \cdot 5 \\
206 \cdot 6 \\
131 \cdot 1 \\
162 \cdot 4 \dagger \\
125 \cdot 2 \\
164 \cdot 1 \dagger \\
96 \cdot 7 \\
80 \cdot 3 \\
86 \cdot 3 \\
190 \cdot 3 \\
125 \cdot 3 \\
231 \cdot 2 * \\
89.1 \\
82 \cdot 1 \\
83 \cdot 1 \\
93 \cdot 5 \\
99 \cdot 9 \\
76 \cdot 1 \\
92 \cdot 0 \\
129 \cdot 0^{*} \\
75 \cdot 1 \\
277 \cdot 3 \dagger \\
114 \cdot 7 \\
173 \cdot 5 \dagger \\
22 \cdot 8 \dagger \\
31 \cdot 2 \\
15 \cdot 7 \dagger \\
99 \cdot 8 \\
86 \cdot 7 \\
83 \cdot 4 \\
164 \cdot 8\end{array}$ & 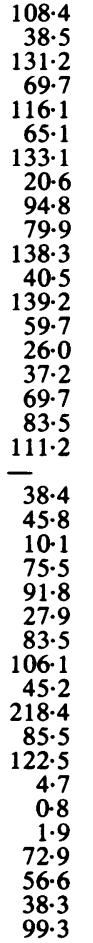 & $\begin{array}{l}120.8 \\
197.7 \\
160.5 \\
249.4 \\
172.8 \\
199.8 \\
242.7 \\
148.4 \\
392.0 \\
202.6 \\
189.5 \\
292.5 \\
192.0 \\
147.9 \\
187.5 \\
169.8 \\
414.5 \\
181.1 \\
425.0 \\
175.5 \\
135.4 \\
299.9 \\
114.6 \\
108.5 \\
165.7 \\
101.0 \\
155.4 \\
117.3 \\
347.9 \\
150.6 \\
238.3 \\
66.6 \\
173.1 \\
56.5 \\
133.6 \\
127.1 \\
158.3 \\
257.5\end{array}$ \\
\hline
\end{tabular}

*Statistically significant at 0.05 level.

†Statistically significant at 0.01 level.

66.17. The SMR was $130 \cdot 0, \mathrm{p}<0.05$. The other neoplasm with significant excess was lymphosarcoma and reticulosarcoma, with eight observed $v$ 3.00 expected $(S M R=266.5, p<0.05)$.

Deaths from diseases of the circulatory system were significantly less than expected. The deficit of pneumonia mortality was also significant. Nevertheless emphysema exhibited a significant SMR of 274.8 (59 observed $v 21.47$ expected, $\mathrm{p}<0.01$ ).

CAUSE SPECIFIC MORTALITY BY JOB CATEGORY As mentioned earlier, partical work histories containing about 200 different job titles were available from the annual dispatch tapes maintained by the union. Assisted by union personnel, these job titles were reduced to 20 functional job titles, which were further grouped into three categories of potential exposure to diesel exhaust emissions. These exposure assignments were based on the description of the duties of the job and the proximity of the job to a diesel exhaust emission source as provided by the union. The 20 functional job titles by potential exposure category are as follows:

High exposure

Scraper operator

Loader operator

Dozer operator

Backhoe operator

\section{Low exposure}

Blade operator

Roller operator

Mechanical maintenance

worker

Engineer (rodman, etc)

Stationary equipment operator

Crane operator

Boom lift operator

Clam shell worker

\section{Unknown exposure}

Oil field worker

Asphalt plant and

paving worker

Concrete and paving

worker

Marine worker 
Table 7 Observed and expected deaths by cause, SMRs, and their $95 \%$ confidence limits for normal retirees (retired at or after age 65 and early retirees who reached age 65) from local 3-3A. (No of subjects $=4075$, person-years $=18677 \cdot 8$ )

\begin{tabular}{|c|c|c|c|c|c|}
\hline $\begin{array}{c}\text { Cause of death } \\
\text { (7th ICDA) }\end{array}$ & $\begin{array}{l}\text { Obs } \\
\text { deaths }\end{array}$ & $\begin{array}{l}\text { Expected } \\
\text { deaths }\end{array}$ & $S M R$ & $\begin{array}{l}\text { Lower } \\
\text { limit }\end{array}$ & $\begin{array}{l}\text { Upper } \\
\text { limit }\end{array}$ \\
\hline 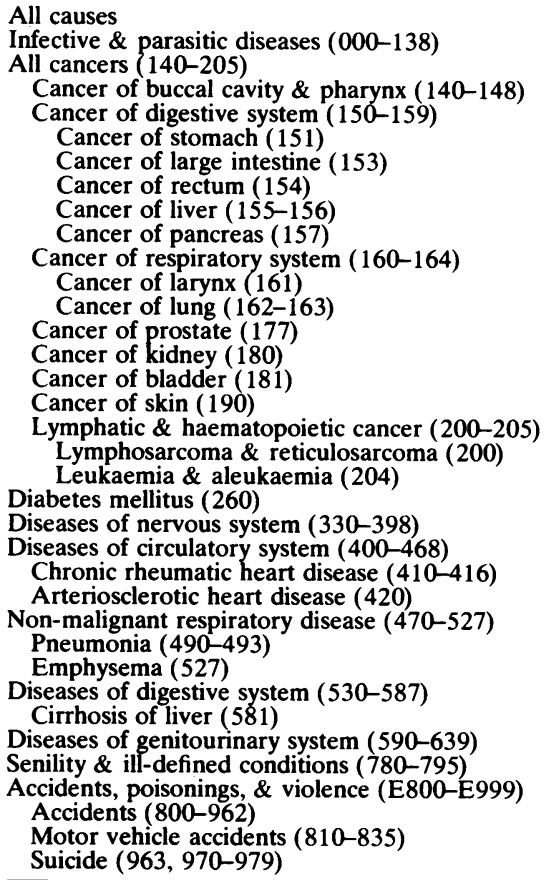 & $\begin{array}{r}796 \\
3 \\
224 \\
5 \\
61 \\
10 \\
25 \\
3 \\
5 \\
13 \\
88 \\
2 \\
86 \\
13 \\
2 \\
5 \\
3 \\
18 \\
8 \\
4 \\
9 \\
67 \\
338 \\
2 \\
258 \\
82 \\
10 \\
59 \\
20 \\
12 \\
1 \\
2 \\
27 \\
16 \\
4 \\
11\end{array}$ & $\begin{array}{r}875 \cdot 36 \\
5 \cdot 25 \\
195 \cdot 23 \\
5 \cdot 24 \\
53 \cdot 99 \\
8 \cdot 82 \\
19 \cdot 28 \\
5 \cdot 94 \\
3 \cdot 33 \\
11 \cdot 21 \\
69 \cdot 31 \\
2.69 \\
66 \cdot 17 \\
18 \cdot 65 \\
4 \cdot 31 \\
7 \cdot 43 \\
2 \cdot 13 \\
16 \cdot 28 \\
3 \cdot 00 \\
6 \cdot 78 \\
14 \cdot 02 \\
80 \cdot 68 \\
421 \cdot 97 \\
5 \cdot 33 \\
355 \cdot 70 \\
68 \cdot 89 \\
20 \cdot 23 \\
21 \cdot 47 \\
29 \cdot 78 \\
12 \cdot 39 \\
10.61 \\
8 \cdot 90 \\
28 \cdot 20 \\
19 \cdot 36 \\
6.77 \\
6.92\end{array}$ & $\begin{array}{c}90.9 \dagger \\
57 \cdot 1 \\
114 \cdot 7^{*} \\
95 \cdot 4 \\
113 \cdot 0 \\
113 \cdot 4 \\
129 \cdot 7 \\
50 \cdot 5 \\
150 \cdot 3 \\
116 \cdot 0 \\
127 \cdot 0^{*} \\
74 \cdot 3 \\
130 \cdot 0^{*} \\
69 \cdot 7 \\
46 \cdot 4 \\
67 \cdot 3 \\
141 \cdot 0 \\
110 \cdot 6 \\
266 \cdot 5^{*} \\
59 \cdot 0 \\
64 \cdot 2 \\
83 \cdot 0 \\
80 \cdot 1 \dagger \\
37 \cdot 5 \\
72 \cdot 5 \dagger \\
119 \cdot 0 \\
49 \cdot 4^{*} \\
274 \cdot 8 \dagger \\
67 \cdot 2 \\
96 \cdot 8 \\
9 \cdot 42 \dagger \\
22 \cdot 51^{*} \\
95 \cdot 8 \\
82 \cdot 7 \\
59 \cdot 1 \\
158 \cdot 9\end{array}$ & $\begin{array}{r}84 \cdot 7 \\
11 \cdot 9 \\
100 \cdot 1 \\
30 \cdot 9 \\
86 \cdot 4 \\
54 \cdot 5 \\
83 \cdot 7 \\
10 \cdot 4 \\
48 \cdot 6 \\
61 \cdot 7 \\
102 \cdot 1 \\
9 \cdot 0 \\
104 \cdot 1 \\
37 \cdot 1 \\
5 \cdot 6 \\
21 \cdot 8 \\
29 \cdot 1 \\
65 \cdot 4 \\
114 \cdot 9 \\
16 \cdot 1 \\
29 \cdot 5 \\
64 \cdot 4 \\
71 \cdot 7 \\
4 \cdot 5 \\
63 \cdot 9 \\
94 \cdot 8 \\
23 \cdot 8 \\
209 \cdot 1 \\
40 \cdot 9 \\
49 \cdot 9 \\
0 \cdot 2 \\
2 \cdot 7 \\
63 \cdot 0 \\
47 \cdot 2 \\
16 \cdot 1 \\
79 \cdot 4\end{array}$ & $\begin{array}{r}97 \cdot 5 \\
166 \cdot 9 \\
130 \cdot 9 \\
222 \cdot 9 \\
145 \cdot 1 \\
208 \cdot 5 \\
119 \cdot 3 \\
147 \cdot 7 \\
351 \cdot 1 \\
198 \cdot 2 \\
156 \cdot 4 \\
268 \cdot 3 \\
160 \cdot 5 \\
119 \cdot 1 \\
167 \cdot 7 \\
157 \cdot 2 \\
412 \cdot 3 \\
174 \cdot 7 \\
524 \cdot 7 \\
151 \cdot 0 \\
121 \cdot 9 \\
105 \cdot 5 \\
89 \cdot 1 \\
135 \cdot 5 \\
82 \cdot 0 \\
147 \cdot 8 \\
90 \cdot 9 \\
354 \cdot 6 \\
103 \cdot 8 \\
169 \cdot 0 \\
52 \cdot 4 \\
81 \cdot 2 \\
139 \cdot 4 \\
134 \cdot 2 \\
151 \cdot 1 \\
284 \cdot 2\end{array}$ \\
\hline
\end{tabular}

*Statistically significant at 0.05 level.

†Statistically significant at 0.01 level.

Table 8 shows the mortality experience of four groups in the high exposure category: scraper operators, dozer operators, loader operators, and backhoe operators. In this analysis scraper operators were those who were dispatched at lease once as such during 1967-78. Among the 4589 scraper operators, 263 deaths were observed, which was $30 \%$ less than expected. The SMR of 69.4 was significantly low at the 0.01 level. Sixty deaths were due to malignant neoplasms. The corresponding SMR of 77.2 was significantly low at the 0.05 level. For the entire subcohort of scraper operators, no significant mortality excess was observed. In particular, mortality from lung cancer was identical with the expected ( 28 observed $v 28.00$ expected).

A total of 6712 union members was ever dispatched as dozer operators and their total mortality was only $67.2 \%$ of the expected; this deficit was significant at the 0.01 level. Mortality from all malignant neoplasms was also significantly low $(\mathrm{SMR}=66.0, \mathrm{p}<0.01)$. Part of the deficit may be attributed to cancer of the digestive system (SMR = $53.4, \mathrm{p}<0.01)$. For lung cancer, there was a non- significant deficit of $25 \%$. For the total group of dozer operators, no significant excess of mortality was detected.

Detailed analysis indicates that among those dozer operators with 15-19 years of membership and 20 or more years of latency, lung cancer mortality was significantly high. Five deaths were due to lung cancer in this subgroup, whereas only 1.46 was expected; the SMR being 343.4, p <0.05. No other significant excess was detected in the detailed analysis.

No significant excess was detected in the group ever dispatched as loader operators. On the other hand, mortality deficits for all causes, all malignant neoplams, cancer of the digestive system, disease of the nervous system and sense organs, diseases of the circulatory system, strokes, and non-malignant respiratory diseases were statistically significant.

Based on the available information, 4042 union members were known to have been dispatched as backhoe operators. Significant mortality deficits were observed for all causes (SMR $=62 \cdot 9$ ), all cancers $(\mathrm{SMR}=60 \cdot 8)$, diseases of the circulatory sys- 
Table 8 Cause-specific SMRs for local 3-3A members who were ever dispatched as scraper operators, dozer operators, backhoe operators, loader operators

\begin{tabular}{|c|c|c|c|c|}
\hline \multirow{2}{*}{$\begin{array}{c}\text { Cause of death } \\
\qquad(7 \text { th ICDA) }\end{array}$} & \multicolumn{4}{|l|}{$S M R$} \\
\hline & $\begin{array}{l}\text { Scraper } \\
\text { operator }\end{array}$ & $\begin{array}{l}\text { Dozer } \\
\text { operator }\end{array}$ & $\begin{array}{l}\text { Backhoe } \\
\text { operator }\end{array}$ & $\begin{array}{l}\text { Loader } \\
\text { operator }\end{array}$ \\
\hline All causes & $69 \cdot 4 \dagger$ & $67 \cdot 2 \dagger$ & $62.9 \dagger$ & $62 \cdot 8 \dagger$ \\
\hline Infective $\&$ parasitic diseases $(000-138)$ & - & $18 \cdot 2$ & - & - \\
\hline All cancers $(140-205)$ & $77 \cdot 2^{*}$ & 66.0† & $60 \cdot 8 \dagger$ & $71 \cdot 3 \dagger$ \\
\hline Cancer of buccal cavity \& pharynx $(140-148)$ & $72 \cdot 5$ & $70 \cdot 7$ & - & $19 \cdot 1$ \\
\hline Cancer of digestive system $(150-159)$ & $63 \cdot 5$ & $53.4 \dagger$ & $84 \cdot 2$ & $63 \cdot 4^{*}$ \\
\hline Cancer of stomach (151) & $128 \cdot 9$ & $46 \cdot 6$ & $93 \cdot 2$ & $84 \cdot 1$ \\
\hline Cancer of large intestine (153) & $32 \cdot 5$ & $47 \cdot 0$ & $70 \cdot 3$ & $25 \cdot 4 \dagger$ \\
\hline Cancer of rectum (154) & - & $23 \cdot 6$ & - & $25 \cdot 7$ \\
\hline Cancer of liver (155-156) & $181 \cdot 1$ & 128.4 & 264.4 & $140 \cdot 3$ \\
\hline Cancer of pancreas (157) & $48 \cdot 2$ & $69 \cdot 7$ & 104.9 & $88 \cdot 2$ \\
\hline Cancer of respiratory system $(160-164)$ & $94 \cdot 9$ & $75 \cdot 6$ & 68.8 & $87 \cdot \overline{2}$ \\
\hline Cancer of larynx (161) & - & $116 \cdot 9$ & - & $85 \cdot 2$ \\
\hline Cancer of lung (162-163) & $100 \cdot 0$ & $74 \cdot 5$ & $72 \cdot 4$ & $86 \cdot 2$ \\
\hline Cancer of prostate (177) & - & $36 \cdot 7$ & - & $21 \cdot 1$ \\
\hline Cancer of kidney (180) & - & - & - & $49 \cdot 1$ \\
\hline Cancer of bladder (181) & $128 \cdot 1$ & $85 \cdot 7$ & $94 \cdot 8$ & $95 \cdot 8$ \\
\hline Cancer of skin (190) & $52 \cdot 0$ & $29 \cdot 8$ & 69.9 & 58.9 \\
\hline Lymphatic \& haematopoietic cancer (200-205) & $71 \cdot 0$ & $69 \cdot 5$ & $81 \cdot 6$ & $71 \cdot 2$ \\
\hline Lymphosarcoma \& reticulosarcoma (200) & - & $54 \cdot 3$ & $216 \cdot 0$ & $140 \cdot 6$ \\
\hline Hodgkins disease (201) & $229 \cdot 2$ & $94 \cdot 6$ & - & $44 \cdot 7$ \\
\hline Leukaemia \& aleukaemia (204) & $32 \cdot 2$ & $51 \cdot 7$ & - & $35 \cdot 2$ \\
\hline Diabetes mellitus (260) & $78 \cdot 1$ & $39 \cdot 4$ & $27 \cdot 5$ & $72 \cdot 8$ \\
\hline Disease of blood (290-299) & 138.9 & $143 \cdot 3$ & $193 \cdot 2$ & $74 \cdot 6$ \\
\hline Diseases of nervous system $(330-398)$ & $49 \cdot 61^{*}$ & $45 \cdot 7 \dagger$ & $56 \cdot 5$ & $41 \cdot 2 \dagger$ \\
\hline Diseases of circulatory system $(400-468)$ & $55.52 \dagger$ & $61 \cdot 5 \dagger$ & $57 \cdot 7 \dagger$ & $52 \cdot 8 \dagger$ \\
\hline Chronic rheumatic heart disease $(410-416)$ & $27 \cdot 0$ & $71 \cdot 1$ & $38 \cdot 1$ & - \\
\hline Arteriosclerotic heart disease $(420)$ & $51 \cdot 7 \dagger$ & $56 \cdot 5 \dagger$ & $54.9 \dagger$ & $52.6 \dagger$ \\
\hline Non-malignant respiratory disease $(470-527)$ & $62 \cdot 5$ & $69 \cdot 6$ & $65 \cdot 7$ & $64 \cdot 1^{*}$ \\
\hline Pneumonia (490-493) & $79 \cdot 0$ & $95 \cdot 2$ & $66 \cdot 7$ & $75 \cdot 3$ \\
\hline Emphysema (527) & $21 \cdot 3$ & $56 \cdot 1$ & $127 \cdot 4$ & $73 \cdot 8$ \\
\hline Diseases of digestive system (530-587) & $46 \cdot 3 \dagger$ & $79 \cdot 2$ & $87 \cdot 7$ & $74 \cdot 3$ \\
\hline Cirrhosis of liver (581) & $51 \cdot 4$ & $88 \cdot 3$ & $115 \cdot 5$ & $89 \cdot 7$ \\
\hline Diseases of genitourinary system (590-639) & $29 \cdot 7$ & $15 \cdot 1^{*}$ & - & $15 \cdot 81^{*}$ \\
\hline Senility \& ill-defined conditions $(780-795)$ & $35 \cdot 9$ & $19 \cdot 4 \dagger$ & - & $9 \cdot 9 \dagger$ \\
\hline Accidents, poisonings, \& violence (E800-E999) & $115 \cdot 9$ & $97 \cdot 4$ & $77 \cdot 3$ & $86 \cdot 1$ \\
\hline Accidents (800-962) & $128 \cdot 0$ & $110 \cdot 5$ & $91 \cdot 0$ & $107 \cdot 9$ \\
\hline Motor vehicle accidents $(810-835)$ & $85 \cdot 9$ & $85 \cdot 0$ & $100 \cdot 2$ & $94 \cdot 3$ \\
\hline Suicide $(963,970-979)$ & $93 \cdot 2$ & $72 \cdot 7$ & $73 \cdot 3$ & $58 \cdot 9^{*}$ \\
\hline $\begin{array}{l}\text { No of subjects } \\
\text { Person-years }\end{array}$ & $\begin{array}{r}4589 \\
53596\end{array}$ & $\begin{array}{r}6712 \\
80328\end{array}$ & $\begin{array}{l}4042 \\
42601\end{array}$ & $\begin{array}{r}7865 \\
89489\end{array}$ \\
\hline
\end{tabular}

*Statistically significant at 0.05 .

†Statistically significant at -0.01.

tem $(\mathrm{SMR}=57 \cdot 7)$, and arteriosclerotic heart disease $(S M R=54 \cdot 9)$.

Only two job title groups in the low exposure category were large enough for statistical analysis: mechanical maintenance workers and engineers. A total of 6008 individuals was dispatched as mechanical maintenance workers. Among these men 396 deaths were observed compared with the expected of 621.81 (table 9). The overall SMR was 63.7, significant at the 0.01 level. All cancers, cancer of the respiratory system, and all lymphopoietic cancers were significantly less than the expected. Significant deficits were also observed for diseases of the nervous system and sense organs, strokes, diseases of the circulatory system, diseases of the respiratory system, and diseases of the digestive system.

For the entire group of mechanical maintenance workers, accidental deaths were only slightly in excess (52 observed $v 47 \cdot 89$ expected). Detailed analysis, however, indicated that for those with 20 or more years of membership, 18 deaths were due to accidents when only 10.62 were expected. The corresponding SMR of 169.5 was significant at the 0.05 level.

Among the 7032 engineers, 364 deaths occurred, which were only $60.9 \%$ of the expected. This deficit was statistically significant at the 0.01 level. Also significant were the deficits for all cancers, respiratory cancers, diseases of the nervous system and sense organs, diseases of the circulatory system, cirrhosis of the liver, and external causes of death.

Detailed analysis showed two significant excesses among the engineers. For those with 15-19 years of membership and 20 or more years of latency, three deaths were due to cancer of the large intestine, 
Table 9 Cause-specific SMRs for local 3-3A union members who were ever dispatched as mechanical maintenance workers and engineers

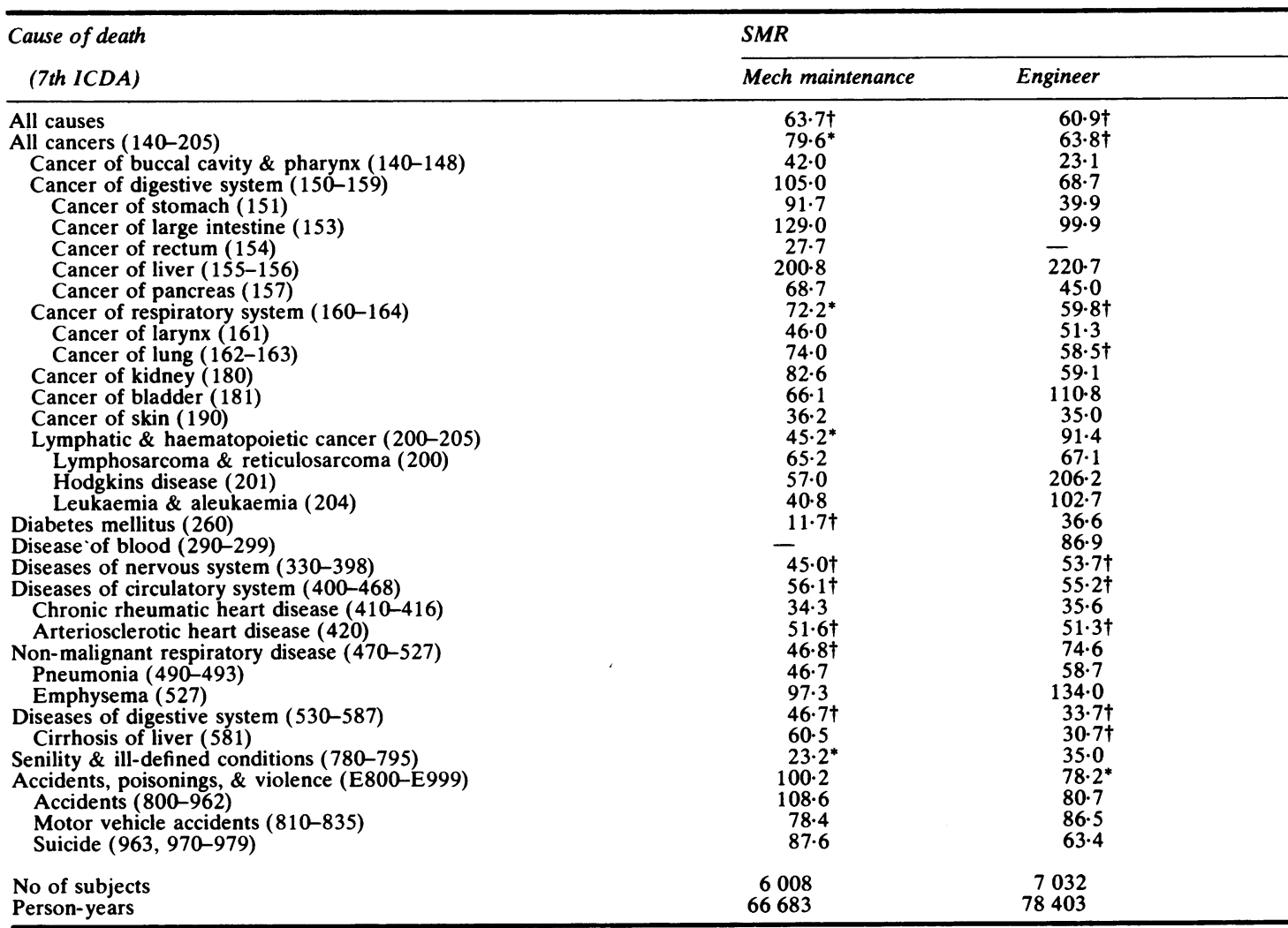

*Statistically significant at 0.05 level.

†Statistically significant at 0.01 level.

compared with 0.37 expected. The SMR of $807 \cdot 2$ was significant at the 0.05 level. For those with $10-14$ years of membership and $10-19$ years of latency, three deaths were from liver cancer, whereas only $0 \cdot 34$ was expected. The liver cancer SMR was $871 \cdot 9, \mathrm{p}<0.05$.

\section{CAUSE SPECIFIC MORTALITY BY EXPOSURE CATEGORY}

Table 10 shows the cause specific mortality by exposure category. A total of $\mathbf{8 8 0 0}$ were dispatched most frequently in job categories ranked as potential high exposure. Significant mortality deficits were found in all causes, all cancers, diseases of the nervous system and sense organs, diseases of the circulatory system, and strokes. No significant excess was detected for any causes examined. In particular, SMR from lung cancer was slightly, but not significantly, lower than expected.

Similar results were found for those dispatched most frequently in job categories ranked as potential low exposure. Significant deficits were detected in the same causes of death, and no significant excess was found.

Among the 3656 individuals dispatched most frequently in job categories with unknown exposure, significant deficits were noted for all causes, all cancers, diseases of the circulatory system, nonmalignant respiratory diseases, and diseases of the digestive system. Mortality from motor vehicle accidents, however, was significantly high ( 21 observed $v 12 \cdot 12$ expected, $\mathrm{SMR}=173 \cdot 3, \mathrm{p}<0.05)$.

Finally, there were 9707 individuals with no dispatch information at all. Overall mortality was exactly as expected. Cancer from all sites, however was significantly high (339 observed $v 338.42$ expected, SMR $=112.0, p<0.05)$. The excess came mainly from cancer of the stomach (30 observed $v 15.07$ expected, SMR $=199.1, \mathrm{p}<$ $0.01)$ and lung cancer (141 observed $v \quad 118.19$ expected, $S M R=119.3, p<0.01)$. In addition, cancer of the liver was high (11 observed $v 5.62$ 
Table 10 Cause-specific SMRs for local 3-3A members who were most frequently dispatched by exposure category (high, low, unknown, no dispatch history)

\begin{tabular}{|c|c|c|c|c|}
\hline \multirow{2}{*}{$\begin{array}{l}\text { Cause of death } \\
\qquad(7 \text { th ICDA) }\end{array}$} & \multicolumn{4}{|l|}{$S M R$} \\
\hline & $\begin{array}{l}\text { High } \\
\text { exposure }\end{array}$ & $\begin{array}{l}\text { Low } \\
\text { exposure }\end{array}$ & $\begin{array}{l}\text { Unknown } \\
\text { exposure }\end{array}$ & $\begin{array}{l}\text { No } \\
\text { history }\end{array}$ \\
\hline 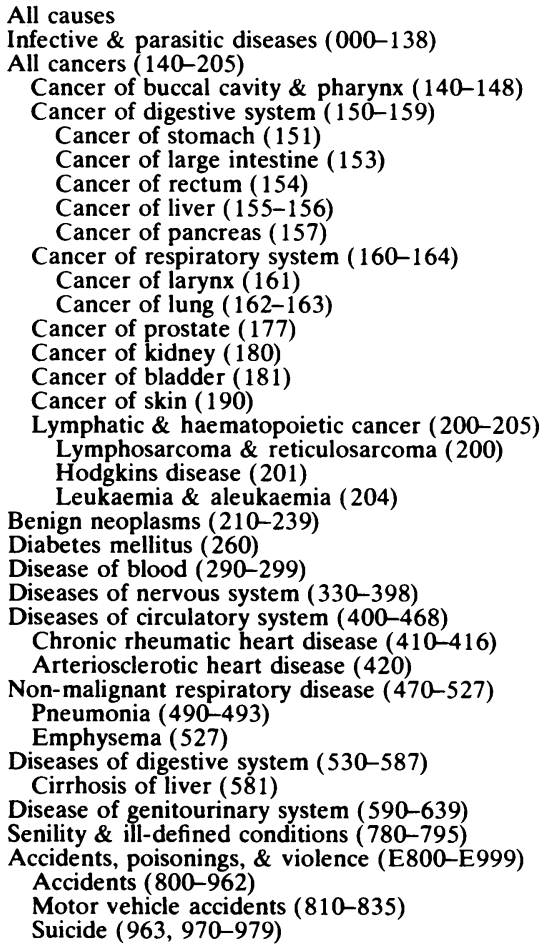 & $\begin{array}{l}71 \cdot 2 \dagger \\
17 \cdot 4^{*} \\
79 \cdot 8 \dagger \\
70 \cdot 9 \\
71 \cdot 5 \\
93 \cdot 5 \\
54 \cdot 9 \\
- \\
173 \cdot 4 \\
93 \cdot 4 \\
92 \cdot 3 \\
79 \cdot 1 \\
93 \cdot 8 \\
19 \cdot 6 \\
22 \cdot 7 \\
118 \cdot 5 \\
81 \cdot 3 \\
89 \cdot 7 \\
130 \cdot 0 \\
123 \cdot 0 \\
16 \cdot 2^{*} \\
46 \cdot 4 \\
76 \cdot 9 \\
137 \cdot 9 \\
57 \cdot 4 \dagger \\
61 \cdot 8 \dagger \\
82 \cdot 0 \\
58 \cdot 0 \dagger \\
75 \cdot 7 \\
93 \cdot 2 \\
87 \cdot 9 \\
72 \cdot 9 \\
79 \cdot 5 \\
-77 \cdot 3^{*} \\
95 \cdot 6 \\
113 \cdot 4 \\
95 \cdot 2 \\
65 \cdot 6\end{array}$ & $\begin{array}{c}67 \cdot 7 \dagger \\
9 \cdot 4{ }^{\dagger} \\
82 \cdot 9 \dagger \\
63 \cdot 5 \\
84 \cdot 0 \\
53 \cdot 5 \\
103 \cdot 5 \\
46 \cdot 0 \\
145 \cdot 2 \\
86 \cdot 6 \\
85 \cdot 0 \\
58 \cdot 9 \\
86 \cdot 0 \\
98 \cdot 5 \\
95 \cdot 3 \\
117 \cdot 6 \\
49 \cdot 5 \\
69 \cdot 0 \\
85 \cdot 9 \\
79 \cdot 9 \\
88 \cdot 2 \\
103 \cdot 8 \\
34 \cdot 4 \dagger \\
- \\
49.9 \dagger \\
60 \cdot 0 \dagger \\
37.9 * \\
56 \cdot 7 \dagger \\
63 \cdot 3 \dagger \\
46 \cdot 5 \dagger \\
118 \cdot 8 \\
58 \cdot 8 \dagger \\
71 \cdot 2 * \\
7 \cdot 3 \dagger \\
20 \cdot 6 \dagger \\
93 \cdot 4 \\
97 \cdot 4 \\
87 \cdot 6 \\
91 \cdot 6\end{array}$ & 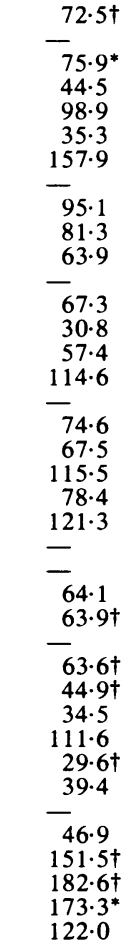 & $\begin{array}{c}100 \cdot 7 \\
159 \cdot 7 \\
112 \cdot 0^{*} \\
100 \cdot 4 \\
109 \cdot 9 \\
199 \cdot 1 \dagger \\
76 \cdot 4 \\
79 \cdot 8 \\
195 \cdot 9 \\
110 \cdot 2 \\
117 \cdot 2 \\
94 \cdot 4 \\
119 \cdot 3^{*} \\
105 \cdot 1 \\
82 \cdot 6 \\
119 \cdot 0 \\
182 \cdot 2 \\
99 \cdot 1 \\
101 \cdot 0 \\
61 \cdot 9 \\
98 \cdot 3 \\
265 \cdot 9^{*} \\
90 \cdot 4 \\
125 \cdot 8 \\
76 \cdot 4^{*} \\
88 \cdot 4 \dagger \\
79 \cdot 2 \\
82.9 \dagger \\
111 \cdot 7 \\
47 \cdot 6 \dagger \\
235 \cdot 5 \dagger \\
95 \cdot 9 \\
100 \cdot 9 \\
41 \cdot 7^{*} \\
26 \cdot 5 \dagger \\
135 \cdot 2 \dagger \\
158 \cdot 1 \dagger \\
123 \cdot 2 \\
124 \cdot 6\end{array}$ \\
\hline $\begin{array}{l}\text { No of subjects } \\
\text { Person-years }\end{array}$ & $\begin{array}{r}8800 \\
97798\end{array}$ & $\begin{array}{r}11993 \\
136891\end{array}$ & $\begin{array}{r}3656 \\
33388\end{array}$ & $\begin{array}{r}9707 \\
104448\end{array}$ \\
\hline
\end{tabular}

${ }^{*}$ Statistically significant at 0.05 level.

†Statistically significant at 0.01 level.

expected, SMR $=195.9, \mathrm{p}<0.05)$. Ten deaths were coded as benign tumours, compared with 3.76 expected $($ SMR $=265.9, \mathrm{p}<0.01)$. Significant excess was also found for emphysema $(\mathrm{SMR}=$ $235 \cdot 5, \mathrm{p}<0 \cdot 01)$ and accidents $(\mathrm{SMR}=158 \cdot 1, \mathrm{p}<$ $0 \cdot 01$ ).

In this category deficits in diseases of the nervous system and sense organs, strokes, and diseases of the circulatory system were significant. Mortality from pnuemonia was less than half the expected (15 observed $v 31.52$ expected, $\mathrm{SMR}=47.6, \mathrm{p}<0.01$ ).

\section{Summary and conclusions}

The overall mortality of this cohort of heavy construction equipment operators union members with potential exposure to diesel exhaust emissions was less (by 18\%) than what one would have expected from a group of United States white men similar in age during the same period; this deficit was statistically significant at the 0.01 level. This observation of a deficit in overall mortality is common in occupational epidemiological studies and may result from several factors: pre-employment selection through physical examination, self selection by those who are physically fit to work, and economic stability enjoyed by regularly employed individuals.

To determine whether any of the potential occupational hazards has an adverse health effect, cause specific SMRs need examination. For the entire cohort, the observed mortality from cancer of all sites was slightly less than expected (SMR $=93 \cdot 0, p$ $<0.05)$. When site specific cancer mortality was examined, a significant deficit was found in cancer of 
the rectum $(12$ observed $v 24.80$ expected, SMR $=$ $48 \cdot 4, \mathrm{p}<0.01)$.

Mortality from cancer of the liver was significantly high. With 23 observed and 13.80 expected, there was an excess of $67 \%(p<0.05)$. Liver cancer has not been previously reported to be in excess among individuals exposed to diesel exhaust. Few chemicals have been directly identified as human liver carcinogens; among those that have are vinyl chloride, arsenic, thorium dioxide, and, possibly, certain aromatic amines. It has been estimated that about $75 \%$ of liver cancers are found in association with cirrhosis. Interestingly, mortality from cirrhosis of the liver for the entire cohort was significantly low $(\mathrm{SMR}=80 \cdot 1, \mathrm{p}<0.05)$.

The apparent excess of liver cancer and deficits of bowel and rectal cancers could represent inaccuracies in certifying the cause of death. In our experience "liver cancer" often reflects secondary cancer rather than primary cancer of the liver. The bowel is the commonest point of origin for these secondaries. If the deaths observed and expected for bowel, rectal, and liver cancers are grouped together the SMR is about 89. Without a further investigation of liver cancer for possible certification errors, no conclusions may be drawn concerning the validity of the raised SMR.

No other site specific cancer SMRs were significantly different from expected. In particular, mortality from lung cancer for the entire cohort was almost identical with the expected (309 observed $v$ 313.44 expected).

Mortality from emphysema was significantly high. Among the 34156 union members, 116 deaths were due to this cause (70.17 expected). The corresponding SMR of 165.3 was significant at the 0.01 level. It is generally accepted that higher rates of emphysema are associated with smoking and occupational exposure to heavy airborne concentrations of dusts, fumes, and gases. The contribution of diesel exhaust, if any, to the observed excess of emphysema mortality in the cohort cannot be satisfactorily estimated. The role of dust exposure is also unclear, although it has been reported that members of the union historically have been exposed to concentrations of respirable dust substantially in excess of permissible levels.

Finally, with regard to cigarette smoking, the results of a survey of a random sample of union members did not indicate any significant difference in smoking habits between the union members and the general population. Of the 107 men participating in the survey, $27(25.2 \%)$ never smoked-that is, smoked less than 100 cigarettes during their entire lifetime. This result was compared with the 1970 National Center for Health Statistics' Health
Interview Survey. ${ }^{15}$ The "never smoked" group in the NCHS survey amounted to $30.7 \%$, slightly higher than the $25.2 \%$ observed in the study survey. The difference, however, was not statistically significant $\left(\chi^{2}=1 \cdot 34\right)$. Although there was no significant difference in smoking habits (\% of nonsmokers) between the study survey and the NCHS survey, it should be emphasised that the sample was relatively small and limited to active union members only. Thus even though it seemed that smoking might not be a likely significant confounding factor in the mortality study, a more definitive statement has to come from a much larger survey.

Accidental deaths among the cohort members are also significantly more than expected. A total of 348 union members died from accidents when the expected was only 273.96 . The $27 \%$ excess was signficant at the 0.01 level. This observation should not come as a surprise, since operating heavy equipment outdoors provides more opportunities for accidents to occur.

Analysis by duration of union membership showed that the excess in cancer of the liver came primarily from those with 10-14 years of union membership. An excess of deaths from cancer of the stomach was also found among these with five to nine years of union membership. No trend, however, was evident in either liver cancer or stomach cancer, and it is difficult to attach any definitive interpretation to these isolated findings. For lung cancer, there seemed to be an increasing trend with duration of union membership; started initially with an SMR of 45 and levelled off around 107.

Mortality from emphysema indicated an upward trend with duration of union membership. For those with more than 15 years of membership, mortality from emphysema was amost twice the expected.

The excess in accidental deaths came primarily from those with 10-14 years of membership, although SMR from accidental deaths was high across all duration of union membership categories.

Analysis by latency indicates clearly an upward trend of mortality with latent period for all causes and all cancers. In addition, the SMR for cancer of the lung also showed a postive trend with latency. For those with a latency of more than 20 years, the lung cancer SMR was almost twice that for those with a latency of less than 10 years.

The steepest gradient occurred among the emphysema SMRs by latency. For those with 20 or more years of latency, the emphysema SMR was almost four times that among those with a latency of less than 10 years.

When cause specific mortality among all retirees was examined, several SMRs were found to be significantly high. A likely explanation for this 
observation is that the all retiree group included some men who had retired early because of ill health. To minimise the potential bias introduced by these early retirements, a separate analysis was performed on those retired at or after age 65 , plus early retirees who lived to reach age 65 . In this group of "normal" retirees cancer of all sites was about $15 \%$ higher than expected (224 observed $v$ 195.23 expected, $\mathrm{p}<0.05$ ).

When site specific cancer mortality among the normal retirees was examined, lung cancer was found to be $30 \%$ higher than expected. This observed rise was statistically significant at the 0.05 level. It should be pointed out that the analysis by duration of union membership did not indicate any significant lung cancer mortality among cohort members with long union membership. The group with 20 or more years of union membership consisted of 11176 individuals, whereas there were only 4075 normal retirees. As such, the retirees were only a small group of the "long timers." A selection bias may have been introduced by retirement, which was partially dealt with by excluding "early" retirees from analysis. Also statistically significant was the excess of mortality from lymphosarcoma and reticulosarcoma.

For non-malignant causes, mortality from emphysema among the normal retirees was highly significant. In this group 59 died from emphysema when 21.47 were expected. The corresponding SMR was $274.8, p<0.01$.

In an effort to correlate mortality experience with past work history, cause specific SMRs were computed for individuals with known specific job dispatches. As mentioned earlier, job dispatch history was available from union computer tapes for 196778 only. For many who were members of local 3-3A before 1967 , the pre-1967 job dispatch history could not be included in the analyses. Furthermore, those who kept the same job throughout 1967-78 would not appear on the dispatch tapes at all.

Cause specific mortality for several broad categories of jobs was analysed, but no significant findings were observed. These job categories were further combined into high and low exposure groups. It should be emphasised that this classification is crude and not based on any environmental measurements. The classification was based on discussion with union personnel who were familiar with the activities in each job, as well as the proximities of the job to diesel exhaust emission sources. Neither the group with potentially high exposure nor the group with potentially low exposure, however, showed any significant excess of mortality. In addition, the group dispatched with jobs of unknown exposure did not show any significant excess of mortality.

Among the 9707 local 3-3A members who did not have any job dispatch history, however, cancer of all sites was significantly high $(\mathrm{SMR}=112 \cdot 0, \mathrm{p}<$ 0.01 ). In particular, the stomach cancer SMR was $199.1(p<0.01)$, the liver cancer SMR 195.9 (p slightly above 0.05 ), and the lung cancer SMR, $119.3(\mathrm{p}<0.05)$. Mortality from emphysema in this group was also significantly high $(\mathrm{SMR}=235 \cdot 5, \mathrm{p}<$ 0.01 ) as was mortality from accidental death (SMR $=158.1, \mathrm{p}<0.01)$. One likely explanation is that this group consisted of union members holding the same job for a long period and, perhaps, had significant potential exposure. Since their jobs remained unchanged, however, they did not show up on the dispatch tapes.

In closing, it should be pointed out that there are several limitations in this study, most of which are typical of a historical mortality study of industrial populations. Although both the proportion of subjects lost to follow up and the proportion of unretrieved death certificates are reasonably low, it is possible, but unlikely, that deaths from certain rare causes might have been missed. For some cases, the dues paid through date might not be the last date of employment in the industry, and duration of union membership might have overstated duration of employment. Only partial work histories were available for some of the cohort members, and mortality analysis by available work history was not conclusive. Historical exposure levels were not available and so no quantification of risk was possible. Even if such environmental measurements existed, without adequate work history no mechanisms could be devised to link exposure with mortality experience. Being a cohort mortality study, the investigation not only inherits all the problems associated with death certificates but also suffers from lack of in-depth clinical information. Employment other than that indicated by the union records (such as other industries) was not considered. Nor was it possible to include smoking history in the analysis, although the relatively small smoking survey mentioned earlier did not indicate any statistically significant difference in smoking habits between union members and the general population.

Despite these limitations, the study has provided suggestive evidence for the existence of several potential health problems in this cohort. The major conclusions may be summarised as follows:

(1) Mortality from liver cancer for the entire cohort was significantly high. Nevertheless, no specific high risk subgroups could be identified. It is not clear whether the excess was related to occupation, life style, or errors in the cause of death certification. 
(2) Although lung cancer mortality was not in excess as a whole for the entire cohort, there were positive trends in lung cancer by latency and duration of union membership. Furthermore, significant lung cancer mortality excesses were found among the retirees and those without dispatch history.

(3) Clearly the cohort experienced a significant mortality excess from emphysema. This association was further strengthened by the observed trends by latency and duration of union membership. Significant excess of mortality from emphysema was also observed among the retirees and those without a job dispatch history. At least on the surface, smoking did not appear to be a major confounding factor, since for the cohort as a whole, lung cancer mortality was not high and diseases of the circulatory system were significantly low.

(4) Mortality from accidental deaths was definitely an occupational hazard in this industry.

\section{Recommendations}

The study has provided suggestive evidence that several causes of death among the cohort members were significantly in excess when compared with the general population of the United States. Various limitations, however, made it impossible to reach more definitive conclusions based on existing data. The most-severe limitation was the lack of adequate work histories. As mentioned earlier, 9707 union members ( $28 \%$ of the total cohort) had no job dispatch history, and it was among this group that mortality from cancer of all sites, stomach cancer, lung cancer, and emphysema was significantly raised. For the remainder of the cohort, only a partial work history (1967-78) was available.

It is recommended that further investigations such as case-control studies on the mortality from lung cancer and emphysema be considered. These investigations will clarify the role of occupation and life style in the aetiology of these two diseases, which are usually closely related because of a common agent, cigarette smoking. We also recommend a more intensive follow up of all cases of liver cancer to ascertain the correct primary site. This will allow us to interpret better the liver cancer SMR reported here.
We thank the Coordinating Research Council, sponsor of this study, the staff of the International Union of Operating Engineers, Local No 3, and their trust fund administrators, C W Sweeney \& Co, for their continued participation and guidance. The following contributed to the early phases of the study: Richard L Davis, Donald V Lassiter, Thomas H Milby, Jane Schulman, and Harrison Stubbs.

\section{References}

' Environmental Health Associates Inc. Health effects of diesel exhaust emissions. (Report prepared for the American Mining Congress.) Berkeley, CA: EHA, 1978.

${ }^{2}$ National Research Council. Diesel cars, benefits, risks, and public policy. (Final report of the Diesel Impacts Study Committee.) Washington: National Academy Press, 1982.

${ }^{3}$ Raffle PAB. The health of the worker. $\mathrm{Br} J$ Ind Med 1957; 14:73-80.

4 Kaplan I. Relationship of noxious gases to carcinoma of the lung in railroad workers. JAMA 1959;171:2039-43.

${ }^{5}$ Hueper WC. A quest into the environmental causes of carcinoma of the lung. Washington: US Dept HEW, PHS, 1955. (Public Health monograph No 36.)

${ }^{6}$ Heino M, Ketola R, Makela P, et al. Work conditions and health of locomotive engineers. I. Noise, vibration, thermal climate, diesel exhaust constituents ergonomics. Scand J Work Environ Health 1978;4, suppl 3:3-14.

7 Wegman DH, Peters JM. Oat cell cancer in selected occupations. J Occup Med 1978;20:793-6.

${ }^{8}$ Luepker RV, Smith MC. Mortality in unionized truck drivers. $J$ Occup Med 1978;20:677-82.

' Schenker MB. Diesel exhaust-an occupational carcinogen? J Occup Med 1980;22:41-6.

${ }^{10}$ World Health Organisation. International classification of diseases. 7th rev. Geneva: WHO, 1978.

" March GM, Preininger M. OCMAP: a user-orientated occupational cohort mortality analysis program. American Statistician 1980;34:245.

12 Enterline P, Decoufle P, Henderson V. Respiratory cancer in relation to occupational exposures among retired asbestos workers. Br J Ind Med 1973;30:162-6.

${ }^{13}$ Collins JF, Redmond CK. The use of retirees to evaluate occupational hazards. J Occup Med 1976;18:595-602.

${ }_{14}$ Collins JF, Redmond CK. The use of retirees to evaluate occupational hazards. II. Comparison of cause-specific mortality by work area.J Occup Med 1978;20:260-6.

is National Center for Health Statistics. Cigarette smoking: United States, 1970. (Monthly vital statistics report, Vol 20, No 3, supplement.) Bethesda, Maryland: NCHS, June 1972. 